\title{
Covid-19: Prospering Industries \& Oversize Management
}

\author{
Silvio M. Brondoni*
}

\begin{abstract}
With COVID-19, many businesses have failed, while other industries and corporations have seen profits increase, and are likely to continue to do so postpandemic, in line with the trend of the oversize economy.

Coronavirus 2019 has caused a major economic shock, in addition to its tremendous impact on global health, pushing the biggest corporations towards an outburst of the new, basic drivers of global capitalism (Health; Energy; Food; Communication). That is, the pillars of global competition that start from an oversize management in order to fix the competitive landscapes of large corporations.
\end{abstract}

Keywords: Greece's Economic Crisis; New Drivers of Capitalism; COVID-19; Industries Prospering in the Pandemic; Global Markets; Oversize Management; Ali Baba Group; Nestlé; L’Oréal; Jiangsu Hengrui; The Coca-Cola Company; Chinese Economy; Global Competition

\section{Greece's Economic Crisis and the New Drivers of Capitalism}

The COVID-19 pandemic is a complex, disruptive event with many impacts beyond those related to health, national economies and global competition. While many worldwide companies were challenged to survive, the pandemic also presented many development opportunities for the long-term.

Global corporations operate today in conditions of highly competitive tension in a context subject to political, social, and technological instability. The economic crisis of 2008 recently revealed in Greece the new basic drivers of global capitalism (Health; Energy; Food; Communication) (Figure 1) (Brondoni \& Boccardelli, 2019).

\footnotetext{
$\square$ "Greece's economic crisis is even worse when viewed through statistics that show it imploded from 2008-16, leaving the country dependent on international bailouts that came with devastating austerity measures.

The report showed what was said to be a shocking decline in practically all economic parameters, with the crisis judged as
}

\footnotetext{
*Full Professor of Market-Driven Management, Niccolò Cusano University (silvio.brondoni@ unicusano.it) 
unprecedented for a developed country that is not afflicted by military conflict or natural disaster.

Personal incomes and private consumption have plummeted, except for tax cheats, politicians and the rich who are thriving during the crisis and even prospering from it.

Greece has been surviving on three rescue packages of 326 billion euros ( $\$ 344.24$ billion) that came with big pay cuts, tax hikes, slashed pensions, a reduced minimum wage and the sell-off of the state's assets to pay back international banks.

Greece's Gross Domestic Product (GDP) reached 175.888 billion euros in 2016, marginally up (190 million euros) from the previous year, 2015, when Tsipras sought and accepted a third bailout, this one for 86 billion euros (\$90.81 billion) he swore he would never do. The 2008-2016 period was marked by a distinct implosion. As part of that, he has continued an onslaught of austerity, including tax hikes, which have scared off foreign investors and worsened the economy, although he claimed it has recovered, rejecting statistical data to the contrary" (The National Herald, 2017).

口 "Greece has confronted serious financial problems since 2008 when the global financial crisis reached its peak. The disturbance in the markets led to an unprecedented local debt crisis. The consequences of crisis were devastating in society. The state countermeasures have triggered a surge in unemployment, emigration, poverty and exclusion, especially among youngsters... In fact, Greece is falling apart into a slow socioeconomic death spiral. More and more extensive cuts and numerous taxes choked every possible and realistic solution, whereas the Troika's countermeasures have weakened the taxpayers' ability to pay their obligations to the state. As a result, in a few years the bank savings have almost been halved because people struggle to maintain a viable way of living" (Mavridis, 2018).

The Greece's 2008 international economic crisis represented a sort of 'experimental laboratory', which highlighted the new drivers of modern capitalism. That is, the pillars of global competition that starts from the oversize economy to fix the competitive landscapes of wealth and poverty of nations and large corporations.

The new drivers of capitalism are made up of business areas of defensible innovations that concentrate the long-term investments of worldwide corporations.

In synthesis, the current basic drivers of global capitalism define an interconnected system of corporate business with very high expectations on profits and specifically regard: Health; Energy; Food; Communication (Brondoni, 2014). 
Figure 1: Global Capitalism. Basic Drivers

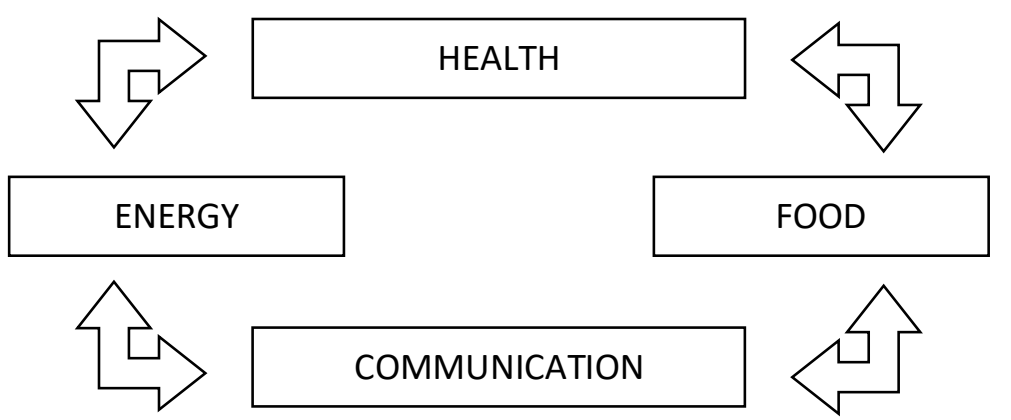

People around the world have been impacted by the coronavirus pandemic. Since 1980, the industrial production of the largest global corporations depends on network production systems with components produced in numerous countries by a complex of companies. A production system that has proved to be very vulnerable in the face of activity blockades caused by the Pandemic.

In addition to COVID-19's tremendous impact on global health, it has caused a major economic shock, pushing the biggest corporations towards an outburst of the new, basic drivers of global capitalism.

\section{Industries That Grow With COVID-19}

The first mechanisms of the crisis were the interruption of many productions and the downfall of consumption in the periods of the most acute spread of the epidemic (the first quarter in China and Italy, the months from March onwards in the rest of Europe and the USA).

Coronavirus brought the world to an arrest, and as a result, for many company and industries (such as air travel, transportation, tourism, and the restaurants industry) and it is still the most difficult problem they have ever had to compete against. With customers and retailers in lockdown, firms wondered how to survive. Many businesses are now experiencing devastating financial consequences from COVID19 , because of supply chain impacts, forced shutdowns, or a significant reduction in consumer spending.

By entering the pandemic, the world had gone into isolation, because social distancing was the most effective way to fight the virus. As a result, anything that relied on human-to-human contact had to be reduced because of the dangers of the virus, and in a contactless world, many interactions with customers and employees became virtual.

COVID-19 accelerated the digital transformation of the global economy. Businesses that developed digital strategies prior to the pandemic were able to obtain large advantages against their competitors.

However, many businesses failed, while other industries and corporations have seen profits increase, and are likely to continue to do so post-pandemic, in line with the trend of the basic drivers of global capitalism. The following examples are an incomplete review of the economic and social disharmony created by COVID-19. 


\subsection{Food Delivery and Online Supermarket Deliveries}

When vulnerable people were advised to stay home, grocery deliveries increased like never before and this strengthened the business of supermarkets as well as the online-only supermarket delivery service. Virtual supermarkets thus saw their sales and profit expectations rise as they continued to thrive during the pandemic.

During the UK's first lockdown British garden centres saw a boost in online sales, as gardeners had more time to spend tending to their plants and crops. The chain has also benefitted from online sales and a new delivery service boosting its profits.

$\square$ Lowe's a US retail giant, hired more than 100,000 workers for the spring season after a surge in demand. Paint, piping, lumber, drills and fittings are among the many products stocked by Lowe's - and its sales have boomed. Americans under lockdown have undertaken more DIY projects and bought the necessary equipment from the home improvement retailer, whose stores have been allowed to stay open throughout the crisis (Henson, 2021).

The pandemic rapidly changed consumer behavior, consumption patterns, and ways of thinking towards online channels, producing a boost of online services. The COVID-19 worldwide outbreak has led to a major change in business conditions for families and corporations.

After selling at very low capacity, many restaurants and bars across the world turned to take-away and delivery services. Many restaurants and cafés decided to facilitate take-away orders so they could continue operating during lockdown.

$\square$ Nestlé, the world's largest food corporation, reported a boost of sales from higher purchasing of its frozen food, coffee and Purina pet care range (Schneider, 2021).

口 "Since the coronavirus outbreak began, The Coca-Cola Co. focused on ensuring products are delivered safely to the stores and communities that need them, while taking every precaution to protect our employees' well-being. At Coca-Cola, we are doing our part to help prevent the further spread of the virus, while also supporting the needs of our customers, consumers, employees and communities. The safety of Coca-Cola system employees is our highest priority. Around the world, local teams have closely followed guidance from health authorities to protect the health and safety of employees across offices, production, distribution and retail facilities. Coca-Cola implemented additional cleaning and sanitization routines, focusing on high-touch surfaces, and token steps to restrict visitors to production facilities. The Coca-Cola Company has asked the majority of office-based employees to work remotely and suspended most travel, both international and domestic" (The Coca-Cola Company, 2020). 
The COVID-19 crisis has accelerated a trend that was already in motion. Thanks to the pandemic, the food delivery industry grew rapidly in 2020. Consumers changed the way they shopped for groceries during the COVID-19 pandemic lockdown in the first half of 2020, and their shopping behaviors have continued to evolve during the crisis (Günday et al., 2020).

\subsection{Online Shopping}

The efforts to contain the pandemic has changed the behaviour of consumers. Home delivery services, such as Amazon, largely benefitted from COVID-19. Online demand has increased for many product categories, such as entertainment and food as well as beverages with innovative non-contact formats. The pure online companies (Nyrop et al., 2020) have largely captured the extraordinary demand within certain categories.

With people stuck at home, online orders were the only way to shop for nonessential items. As many physical outlets were closed, consumers turned to online shopping, even those who had always been historically reluctant to do so. In particular, grocery delivery services became of high demand. Consumers could choose their products, pay online, and leave feedback all on one simple app.

$\square$ Amazon became the emergency port of call for those desperate citizens indoors, to stock up on vital household goods - a situation that led the company to temporarily shut its 'non-essential products'. Record revenues followed, but also soaring costs virus mitigation, such as testing labs and thermal cameras

$\square$ PayPal, the pioneer of online payments, has found increased relevance in the real-world pandemic, generating new capabilities for merchants to facilitate the transfer of money and to handle contactless payments in physical stores.

$\square$ Alibaba Group, the China's ecommerce giant, experienced stagnating sales at its core Tmall and Taobao online marketplaces suffering the undermanned courier partners.

$\square$ L'Oréal, the world's biggest cosmetics company's, experienced booming sales during the Covid-19 crisis, thanks to its heavy investments in marketing and online selling (especially for the soft marketing and sales capabilities of the parent company Nestlé).

$\square$ Apple's 500 stores around the world were forced to close, but revenues were growing thanks to online sales and an everexpanding ecosystem of wearables and services, as millions of consumers working from home would upgrade their electronic devices. 


\subsection{Online Meeting Platforms}

Computing Platforms. With Covid-19, many corporations had to adapt to allow employees to work from home, consequently the teams' communication app became a way for workers to stay in touch through remote working. In a very short time, the cloud has become an important edge of the virtual meetings for many companies.

$\square$ Zoom, boomed during the crisis, and saw its stock price surge by over $100 \%$ in just two months. Google made the premium features of its platform Google Hangouts free until the end of September, and Microsoft saw daily users of its software Teams jump from 32 million to 44 million during March.

Having used their home working space and enjoyed the lack of commuting, many workers focused on remote working very frequently, and platforms provided by Google, Zoom, Microsoft, and others boomed in high demand to keep people connected.

Dating Apps. COVID-19 prohibited nearly all face-to-face meet-ups, and dating apps became the ideal means of finding a partner, with an explosion in downloads and interactions through the likes.

Online Teaching. Online learning resources boomed because many parents had to become teachers overnight. In many Nations, online teaching was already a part of the traditional education system. The Covid-19 restrictions forced the education system to move online, and many of those temporary alterations to the traditional classroom experience will now become permanent changes.

E-Learning Resources. The lockdowns prompted many people, not just students, to try new e-learning resources to pass the time. The ease and low cost of pursuing new hobbies from home have been the keys of success for e-learning companies. Cooking lessons with top chefs, writing classes from best-selling authors and drama classes are among the courses that users can acquire. The virtual workshop platforms have seized the opportunity to rapidly grow, entertaining and educating people who were looking to fill their time.

Online Fitness. With coronavirus, the online fitness industry also boomed. When many gyms and fitness studios had to close, those able to offer their fitness services online reaped the benefits. Many people appreciated the privacy and flexibility of exercising at home and particularly appreciated their new online exercise schedules.

$\square$ British fitness instructor and TV personality Joe Wicks quickly
adapted and during lockdown hundreds of thousands of households
tuned in for his child-friendly YouTube workouts each morning.
Wicks raised his profile globally, as well as a lot of money for
charity. Similarly, actor Chris Hemsworth's fitness app Centre saw
a 300\% increase in downloads in April, while interactive at-home
fitness system Mirror saw product sales double during the
pandemic, according to CNN.

Cybersecurity. The COVID-19 crisis has amplified the dependence on the virtual world. An increasing dependency on virtual meeting platforms means that private 
data are more vulnerable to hacking, and consequently cybersecurity becomes more critical than ever before. Coronavirus has pushed corporations to move their services online, but not all the necessary measures may have been taken to ensure that the data were as protected as they needed to be in a time of rising cybercrime. The growing threat posed by the COVID-19 accelerated the trend of businesses spending more on online safety measures.

\subsection{Online Entertainment \& the Books Industry}

Coronavirus has offered traditional gamers time to play their skills, as well as the opportunity for non-gamers to understand what it is about. Video games sales are definitely on the rise thanks to the pandemic.

$\square$ In March, the release of Nintendo game Animal Crossing: New Horizons saw higher sales than all of the series' previous games combined. Similarly, game streaming platform Twitch saw a $10 \%$ increase in its global usage in the same month, according to gamingindustry.biz.

$\square$ NetEase, the Chinese gaming group, known for its mobile title Fantasy Westward Journey, benefited from millions of its users being at home and seeking entertainment due to the Chinese coronavirus outbreak. The four-fifths company revenues derive from video games (https://www.lovemoney.com/).

The pandemic has also "popularised and legitimised" esports - playing sports competitively via a console. Esports had initially looked to suffer at the outbreak of coronavirus as the games rely on live sporting events, and esports revenue has historically come from advertising and broadcasting. However, when live sports stopped, esports offered fans a way to keep the games going, and it is only set to expand as sports leagues use the medium to engage younger fans (https://www.lovemoney.com/).

$\square$ With the closure of cinemas across the globe people stayed home, Netflix added many subscribers, becoming the largest paid streaming service entertained global lockdown audiences.

$\square$ Chinese people isolated at home turned to Tencent's virtual worlds. Tencent's video subscribers rocketed, its music streamers jumped and monthly users of its social media app WeChat hit a global spending. Tencent acquired Norwegian game developer Funcom, took a stake in German developer Yager, and poured capital into an array of fintech start-ups. (McMorrow, 2020)

$\square$ Music listening habits changed as people sheltered at home. Spotify benefited from a business based largely on subscriptions. People at home turned to meditation and wellness podcasts, 
instrumental music and chilled-out tunes to help manage stress (Bradshaw, 2020).

With the coronavirus, even the books industry started to boom, as many people working from home limited social contacts. Many bookshops around the world were forced to close, and publishing companies imposed cut costs in anticipation of the economic downturn brought about by the pandemic. While streaming services have reaped the benefits of a captive audience, so have more traditional hobbies, such as reading. Book sales were a bright spot for retailers, as people in lockdown around the world looked for romances, children novels and educational titles to help them get through isolation.

$\square$ In the UK, fiction sales climbed by a third and children's educational titles went up $234 \%$ to the third-highest level on record in the final week of March, according to a BBC report. Similarly, in the US there was a $66 \%$ lift in sales of children's non-fiction books in the week ending 21 March, according to the NPD Group.

\subsection{Pharmaceuticals, Personal Protective Equipment, Personal Cleanliness Products and Digital Health Services}

Pharmaceuticals. The Pharmaceuticals industry boomed, as companies such as Pfizer and Moderna created vaccines against COVID-19. The global crisis of COVD19 has demonstrated that health is really one of the four critical drivers of the new global capitalism. In fact, with the pandemic people saw how crucial the pharmaceuticals industry is in worldwide evolution. Prevention and treatment research is very important, many coronavirus vaccines have been found, and the drug discovery market continues to climb in value.

$\square$ Roche, which is one of the diagnostics 'Big Four', benefited from the rollout of its tests for coronavirus, and by checking for antibodies. Its high-throughput machines are also used to quickly process hundreds of tests.

$\square$ Alibaba Health Information, a Hong Kong-listed company controlled by Jack Ma, focused on pharmaceutical ecommerce and operated China's drug product identification, authentication and tracking system. The company benefited from providing internet medical services during the first period of the Covid-19 emergency (Hale, 2020).

Samsung Biologics is a subsidiary of Samsung, focused on manufacturing biopharmaceuticals. The company gained from producing Covid-19-neutralising antibody products.

$\square$ Shanghai-listed Jiangsu Hengrui Medicine develops and produces high-quality generics and innovative drugs. It focuses on oncology, cardiovascular, surgical anaesthetics and endocrine 
therapeutic treatments. The company is benefiting from mandatory biological equivalency tests that aim to eliminate inferior generics (Wang, 2020).

$\square$ Chongqing Zhifei Biological Products is listed in Shenzhen, focusing on vaccine $R \& D$. Zhifei is the Chinese distribution partner of Merck to sell its approved vaccines in China. A subsidiary of Zhifei is developing a vaccine against Covid-19.

$\square$ "Despite multiple vaccines becoming available, there remain vast global health needs further exasperated by the unpredictability of virus variants. Sanofi is continuing to complement its expertise and resources with that of our peers to help prevent and control the pandemic over the long term." (Hudson, P., CEO Sanofi, May 27, 2021 https://www.sanofi.com/en/)

$\square$ The COVID-19 pandemic is an unrivalled scientific and global health challenge. MERCK \& Co knows that success will require global collaboration among countries and companies and more. That is why we have entered a partnership to support the manufacturing and supply of Johnson \& Johnson's COVID-19 vaccine and are working on advancing our therapeutic candidate. (MERCK \& Co, https://www.merck.com/research-and-products/covid-19/).

The successful vaccines for coronavirus boosted pharmaceutical shares, and underlined the importance of the drug discovery market.

Personal Protective Equipment. Personal protective equipment (PPE) has been one of the most talked-about resources of the pandemic. Nations that rely on imports from other countries such as China have noticeably been caught short of this vital device. Most PPE have expiry dates, and so constant supplies of fresh equipment are needed to keep reserves well stocked, meaning that manufacturers will be kept in business to meet the new demand.

Personal Cleanliness Products. With COVID-19, hygiene practices have become an intrinsic part of people's day-to-day routine. People around the world bought large quantities of antibacterial hand gels and soaps as soon as it became apparent that an infectious disease was spreading. Moreover, hand sanitising stations were installed in most public places and businesses, generating a new big business for companies focused on personal cleanliness product production and distribution.

Digital Health Services. Hospitals across the world registered a great collapse of patients coming in to seek emergency medical attention. Patients wanted to avoid visits to hospitals and doctors, and for this reason, many have instead been relying on remote medical services.

Much of America's healthcare system has gone digital to alleviate some of the strain imposed by the coronavirus. Telemedicine and remote diagnostics are helping patients get medical advice and diagnoses at home so they do not need to come in to the doctor's office or hospital, and 3D printing is being used 
to expedite the production of critical medical supplies. The US and Australian governments have approved reimbursement for videolink consultations to keep people away from hospitals, while the UK's National Health Service has launched a chatbot for coronavirus advice.

$\square$ Systems such as Now in Europe and Teladoc Health in the US have been seeing patients use their platforms as the pandemic have been discouraging people from leaving home. Remote diagnosis and treatment service Zoonosis reported a staggering 3,600\% increase in its usage as a result of coronavirus. Governments are recognizing the importance of offering virtual treatment where possible, and in March the US government announced that there would be an expansion of telemedicine services across America.

\subsection{Electric Cars, Electric Scooters and E-Bikes}

Electric Cars. With the pandemic, the travel industry was forced to eliminate nonessential travels, and oil prices slumped as a result. However, the car-making industry was already in trouble due to a worldwide growing awareness of the environmental impact of traditional cars. The pandemic has boosted the green problem, and so car producers have now turned towards green technologies.

$\square$ Electric car producer Tesla saw its share price go up by $492 \%$ in 2020, while carmaker Audi has created a new department called Artemis that is focused solely on getting its electric vehicles to market quicker than planned.

More people were looking for a better environment with their choice of car, and this trend is likely to continue even after the end of COVID-19.

$\square$ CATL, the China's largest manufacturer of batteries for electric vehicles has highlighted new deals and technical breakthroughs. The Shenzhen-listed company is a supplier to global carmakers such as Volkswagen, Daimler and Volvo. The Chinese group is investing in a German battery plant. CATL is aiming to build a recycling factory for battery materials in the central Chinese province of Hubei. Specifically, the group is planning a joint venture with the company Hubei Yehuda Chemical Industry to recycle materials such as cobalt and lithium from used batteries of electric vehicles.

$\square$ LG Chem, a South-Korean corporation, supplies many of the top auto groups. It supplies more than a third of the electric vehicle battery supplies and it is focused to overtake Japanese rival Panasonic and become the global market leader of electric vehicle batteries. 
Electric Scooters and E-Bikes. With COVID-19, people were avoiding public transportation and seeking individual mobility alternatives. The micro-mobility solutions for urban areas - including rentable electric scooters - rocketed thanks to the COVID-19 pandemic. Despite controversies over safety, many cities have introduced electric scooter companies such as Bird, run by Uber, and Lime. The greatest players dominating the electric Scooter Sharing Service market now are: Lime, Bird, Gogoro, Skip Scooters, Vogt Automotive, Yellow, Dot, Mobile, MeiTuan, Spin, Niu International.

$\square$ Rome authorised electric scooters on 1 March 2020, and the Italian authorities have seen the electric scooters as a viable greener alternative to cars. The UK also authorised the use of escooters from 4 July 2020, and London created car-free zones the biggest in Europe.

With the pandemic's social distancing rule, many people decided not to take public transportation and turned towards individual mobility options. In this situation, electric two-wheelers became the most convenient, time-efficient and energyefficient solution for short door-to-door distances. Risk of infection was the main reason for choosing electric scooters and e-bikes as a mode of transportation, rather than speed or cost.

Lanes for cycling and e-cycling were successful while many people worked from home, but new infrastructures could be needed when traffic returns to normal levels.

From the producers of electric scooters and e-bikes point of view, the pandemic caused a big shock in the industry by disrupting their supply chain and their inventory levels. Nonetheless, the e-scooters and e-bikes markets have seen a massive increase in sales over the last two years.

\subsection{Cycling Industries}

As people avoid public transportation in many cities in order to reduce the risk of infection, many others have turned to traditional methods of urban travelling. The pandemic made people aware, and afraid, of mass transit and cycling became a safe alternative to public transportation, because a bicycle is the perfect vehicle for socialdistancing in transportation.

$\square$ According to figures from the NPD Group's retail tracking service, bicycle sales in the United States soared in March 2020, with some categories seeing growth rates of more than 100 percent compared to the previous year (Richter, 2020).

$\square$ The main effect of COVID-19 on mobility in the Netherlands appeared to be a shift away from public transport towards other modes of transportation. Due to the fear of infection with the coronavirus, the Dutch workforce preferred to travel by car, bike or motorcycle. This did not only result in an increase of car travel, but also in the growth of sales figures for (electric) bicycles or motorcycles. The e-bike seemed to be especially popular, as 
VanMoof - one of the most popular e-bike brands - reported a sales increase of 50 percent during the pandemic (Wagner, 2020.)

Covid-19 brought about a dramatic increase in bicycle sales. More and more people chose this very basic form of mobility to fight anxiety in public transportation. Indeed, some nations rewarded the purchase of new bikes or bike maintenance expenditures to encourage ridership during the pandemic. Many majors of the biggest cities saw the opportunity to facilitate the resurgent, socially distant hobby, understanding that public transportation would be either unsafe or undesirable until the pandemic flattened, even if bicycle manufacturers depend upon a multifaceted, geographically dynamic chain of production, with parts arriving from across the globe.

\subsection{Paper and Pulp Industries}

The paper and pulp industries comprise companies that use basic raw materials (e.g. wood) to produce pulp, paper, paperboard, and various cellulose-based products. Such activities are closely related to social civilization and the development of the global economy.

The pulp and paper industry involves many fields such as forestry, agriculture, chemicals, biology, distribution, and transportation, thus occupying an important position in the global economy (Huang et al., 2019).

The COVID-19 pandemic favored great challenges to the pulp and paper industry, creating positive demand for a variety of paper products such as personal hygiene paper products, food-packaging products, corrugated packaging materials, and medical specialty papers (Liu et al., 2020).

The worldwide paper industry anticipated new business models. On the one hand, multinational companies have contributed to eco-friendly production processes focused on recycling waste into a product that can be fed back into the new process. On the other hand, medium and large non-internationalized companies believed that such outcome would constitute a key factor in the much-needed market repositioning, with widespread recognition of innovative production processes and products with a benefit shared at the international level (Rizzi \& Danesi, 2021).

\subsection{Plastics Industries}

Plastics are a very important material (e.g. lightweight, cheap, durable, tough, resistant, easy to manufacture, etc.), with a large number of applications, such as in packaging, automotive, construction, agriculture, and healthcare industries, with undisputable benefits over other materials (e.g. metals, glass) (Andrady \& Neal, 2009).

With COVID-19, plastic manufacturers are seeing production increase during a global economic downturn. Many types of single-use plastics may have been affected directly or indirectly by the response to the COVID19 pandemic.

$\square$ Plastics lobbyists have been everywhere during the pandemic, touting the role their products play in keeping food, health-care workers, and families safe. It has been a sharp turnaround for a 
sector that, only a short time ago, looked like a pariah. Under pressure from both investors and consumers, companies were setting targets to reduce their reliance on plastic packaging including Coca-Cola Co.

Up to the coronavirus pandemic, every indication seemed to suggest that the U.S. was poised for a plastics boom of epic proportions. The growth of plastics was certainly due to people's perceptions of those as resistant to COVID-19 transmission. Masks, gloves and other protective equipment are made from plastics; so are the delivery cartons, soda bottles and other single-use packaging that retailers used and discarded as they ordered more food and consumer goods delivered to their homes.

$\square$ Plastic was the only segment of the U.S. chemistry industry, which includes everything from fertilizer to synthetic rubber, to expand last year (American Chemistry Council, 2020).

$\square$ The focus on plastic waste reduction has since been overshadowed by the COVID-19 pandemic. Traditionally minor sources of plastic pollution - including personal protective equipment (PPE) - have become far more prominent, exacerbating consumption. Moreover, some regulatory measures meant to reduce plastic have been delayed and/or rolled back during the pandemic, stalling or even reversing the longstanding global battle to mitigate plastic pollution (Yuan et al., 2021).

One of the most visible effects of the pandemic was a surge in the demand for disposable protective equipment made of plastics, such as face masks and gloves not only used in medical environments, but as personal protection equipment for the general population. Overall net effects for single-use packaging for food take-away and delivery services and e-commerce packaging is difficult to estimate, as no reliable data on the net demand is available (Graulich et al., 2021).

$\square$ The coronavirus pandemic has sparked a rush for plastic. From Wuhan to New York, demand for face shields, gloves, takeaway food containers and bubble wrap for online shopping has surged. Since most of that cannot be recycled, so has the waste (Brondoni, 2020). But there is another consequence. The pandemic has intensified a price war between recycled and new plastic, made by the oil industry. It is a war recycler worldwide are losing, price data and interviews with more than two dozen businesses across five continents show (Brock, 2020).

Despite the health, social, economic and financial impacts of the COVID-19 pandemic, China increased its plastics production and market share from $31 \%$ to $32 \%$, in line with the growth of its customer industries. The North American market share remained stable at around $19 \%$ of the global production, while Europe's production decreased by more than $5 \%$, from around 58 million tonnes to 55 million 
tonnes, representing a loss of 1 point of market share (from $16 \%$ in 2019 to $15 \%$ in 2020) (Plastics Europe. Association of Plastics Manufacturers, 2020).

\section{Bibliography}

Andrady, A. L., \& Neal, M. M. (2009). Applications and Societal Benefits of Plastics. Philosophical Transactions of the Royal Society B, 364, 1977-1984.

http://dx.doi.org/10.1098/rstb.2008.0304

Andreosso-O'Callaghan, B. (2020). Industrial Policy Response to the Covid 19 Crisis in Ireland - A Filière Approach. Symphonya. Emerging Issues in Management (symphonya.unicusano.it), (2), 80-88. http://dx.doi.org/10.4468/2020.2.09andreosso

Berend, I. (2017). The Contemporary Crisis of the European Union. Prospects for the Future. New York: Routledge.

Bianchi, P., \& Labory, S. (2020). Industrial Policy After the Covid Crisis: Mobilising All Levels of Government for Smart Complementarity. Symphonya. Emerging Issues in Management (symphonya.unicusano.it), (2), 73-79.

http://dx.doi.org/10.4468/2020.2.08bianchi.labory

Bitzenis, A., Papadopoulos, I., \& Vlachos, v. (2013). Reflections on the Greek Sovereign Debt Crisis. Newcastle: Cambridge Scholars Publishing.

Bradshaw, T. (2020). Companies Prospering in the Pandemic: Spotify, Financial Times, 19 June.

Brondoni, S. M. (2020). US, China, Japan, SK \& EU: Industrial Strategies and Global Firm Challenges. Symphonya. Emerging Issues in Management (symphonya.unicusano.it), (2), 89-103.

http://dx.doi.org/10.4468/2020.2.10brondoni

Brondoni, S. M. (2020). Competitive Circular Economy Management. The Mitsubishi Corporation Case. Symphonya. Emerging Issues in Management (symphonya.unicusano.it), (1), 10-25.

http://dx.doi.org/10.4468/2020.1.02brondoni

Brondoni, S. M., \& Boccardelli, P. (2019). Ouverture de 'IR 4.0, Network Economies \& Stakeholder Engagement'. Symphonya. Emerging Issues in Management (symphonya.unicusano.it), (2), 1-7.

http://dx.doi.org/10.4468/2019.2.01ouverture

Brondoni, S. M. (2019). Shareowners, Stakeholders \& the Global Oversize Economy. The Coca-Cola Company Case, Symphonya. Emerging Issues in Management (symphonya.unicusano.it), (1), 16-27.

http://dx.doi.org/10.4468/2019.1.02brondoni

Brondoni, S. M. (2019). 4.0 IR, Oversize Economy and the Extinction of Mammoth Companies. Symphonya. Emerging Issues in Management (symphonya.unicusano.it), (2), 8-24.

http://dx.doi.org/10.4468/2019.2.02brondoni

Brondoni, S. M. (2018). Competitive Business Management and Global Competition. An Introduction, in Brondoni, S. M. (ed.), Competitive Business Management. A Global Perspective. New York \& Turin: Routledge \& Giappichelli.

Brondoni, S. M., \& Bosetti, L. (2018). Ouverture de 'Integrated CSR Management'. Symphonya. Emerging Issues in Management (symphonya.unimib.it), (1), 1-17.

http://dx.doi.org/10.4468/2018.1.01ouverture

Brondoni, S. M. (2014). Global Capitalism and Sustainable Growth. From Global Products to Network Globalisation. Symphonya. Emerging Issues in Management (symphonya.unimib.it), (1), 10-31.

http://dx.doi.org/10.4468/2014.1.02brondoni

Ciciotti, E. (2020). A New Territorial-Industrial Policy after the Covid 19 Crisis. Symphonya. Emerging Issues in Management (symphonya.unicusano.it), (2), 25-32.

http://dx.doi.org/10.4468/2020.2.03ciciotti 
Goddard, J. (2021). Covid-19. Civic Universities, Societal Innovation and the Recovery of Local Communities. Symphonya. Emerging Issues in Management (symphonya.unicusano.it), (1), 56-63. https://dx.doi.org/10.4468/2021.1.06goddard

Günday, G., Kooij, S., Moulton, J., Karabon, M., \& Omeñaca, J. (2020). How European Shoppers will Buy Groceries in the Next Normal. McKinsey, December 2, 2020

Graulich, K., Köhler, A., Löw, C., Sutter, J., Watson, D., Mehlhart, G., Egebæk, K. R., Bilsen, V., Bley, F., Manshoven, S., Xhelili, A., Mortensen, L.F., Lippert Tange, I. (2021). Impact of COVID19 on Single-Use Plastics and the Environment in Europe. European Topic Centre Waste and Materials in a Green Economy, 22/06/2021.

Hale, T. (2020). Prospering in the Pandemic: the top 100 Companies, Financial Times, 19 June.

Henson, M. (2021). After a Long Winter, Lowe's Garden Centers Bring Out the Joy of Spring. Lowe, March 19, 2021.

Huang, C., Sun, R., Chang, H. M., Yong, Q., Jameel, H., \& Phillips, R. (2019). Production of Dissolving Grade Pulp from Tobacco Stalk through So2-Ethanol-Water Fractionation, Alkaline Extraction, and Bleaching Processes. BioResources, 14(3), 5544-5558.

http://dx.doi.org/10.15376/biores.14.3.5544-5558

Liu, K., Wang, H., Liu, H., Nie, S., Du, H., and Si, C. (2020). COVID-19: Challenges and Perspectives for the Pulp and Paper Industry Worldwide. Bio Resources. 15(3), 4638-4641.

Mavridis, S. (2018). Greece's Economic and Social Transformation 2008-2017. Social Sciences, 7(1), 9.

http://dx.doi.org/10.3390/socsci7010009

McMorrow, R. (2020). Why Supermarkets Are Struggling to Profit from the Online Grocery Boom, Financial Times, 13 August 2020.

Morgan, K. (2021). After the Pandemic: Experimental Governance and the Foundational Economy. Symphonya. Emerging Issues in Management (symphonya.unicusano.it), (1), 50-55.

https://dx.doi.org/10.4468/2021.1.05morgan

Nyrop, M., Nathan, A., Bøcher Lindquist, M., \& Karlsen, J. T. (2020). COVID-19 Will Permanently Change E-commerce in Denmark. Deloitte, 2020.

Richter, F. (2020). U.S. Bicycle Market. COVID-19 Pandemic Fuels Bicycle Boom. Statista, 22 May 2020.

Rizzi, P., \& Danesi, S. (2021). Policies for the Circular Economy: The Case of Paper Industry. Symphonya. Emerging Issues in Management (symphonya.unicusano.it), (1), 76-84.

https://dx.doi.org/10.4468/2021.1.08rizzi.danesi

Salvioni, D. M., \& Almici, A. (2020). Circular Economy and Stakeholder Engagement Strategy. Symphonya. Emerging Issues in Management (symphonya.unicusano.it), (1), 26-44.

http://dx.doi.org/10.4468/2020.1.03salvioni.almici

Schneider, M. (2021). Nestlé. Reports Full-Year Results for 2020, February 18, Vevey.

The Coca-Cola Company (2020) How The Coca-Cola Company is Responding to the Coronavirus Outbreak 03/23/2020. https://www.coca-colacompany.com/news

The National Herald (2017). Statistics Reveal Collapse of Greek Economy Since 2008, March 9, 2017.

Wagner, I. (2020). Effects of Coronavirus on Two-Wheeler Sales in the Netherlands 2020. Statista, November 10, 2020.

Wang, X. (2020). Prospering in the Pandemic: the top 100 Companies, Financial Times, 19 June.

Yuan, X., Wang, X., Sarkar, B. (2021). The Covid-19 Pandemic Necessitates a Shift to a Plastic Circular Economy. Nature Reviews. Earth \& Environment, 2, 659-660.

https://doi.org/10.1038/s43017-021-00223-2 